\title{
RECENT TRENDS OF GLUCOSE-6-PHOSPHATE DEHYDROGENASE DEFICIENCY AMONG SAUDI POPULATION IN RIYADH CITY
}

\author{
TENDÊNCIAS RECENTES DA DEFICIÊNCIA DE GLICOSE-6-FOSFATO \\ DESIDROGENASE ENTRE A POPULAÇÃO SAUDITA NA CIDADE DE RIADE
}

\author{
FATMAH SAID ABDULLAH AL QAHTANY ${ }^{1}$ \\ 1. Associate Professor \& Consultant, Head of Hematopathology Unit, Pathology Department, College of Medicine, King Saud \\ University Medical City, King Saud University, Riyadh, Kingdom of Saudi Arabia, fatma@ksu.edu.sa, fatma.qahtani@yahoo.com
}

\begin{abstract}
G6PD deficiency is associated with erythrocyte deficiency in the X-chromosome enzyme. It causes a hematologic syndrome called hemolytic anemia that connects G6PD deficiency with Xlinked condition. In the Middle East, including Saudi Arabia, G6PD deficiency is the most dominant genetic blood disorders. It results in higher rates of mortality and morbidity due to its incurable long-lasting nature and prevalence of physical and psychological incapacities. In this study, an attempt was made to evaluate the prevalence of G6PD deficiency among the Saudi population in Riyadh city. A cross-sectional retrospective study was conducted at King Saud University Medical City in Riyadh, Saudi Arabia. The population of the study comprised randomly chosen males and females who visited the hospital from January 2017 to January 2018. Statistical analyses were performed using SPSS, and descriptive analysis was used to find the frequency of G6PD-deficient patients. Out of the 209 patients, 62.2\% were males $(n=130)$ and $37.8 \%$ were females $(n=79)$. Twenty males and 6 females were found to have G6PD deficiency, with the male to female ratio being 1:3. Out of the total 130 male participants, 20 patients were found to be enzyme deficient and 6 patients of 79 female patients were found to be G6PD deficient. There were $38.4 \%(n=10)$ patients with G6PD level $<4$ units/gram hemoglobin, 26.9\% $(\mathrm{n}=7)$ patients had G6PD levels of 4.1-7.0 units/gram hemoglobin, and 34.6\% $(\mathrm{n}=9)$ patients had $>7$ units/gram hemoglobin. Among the G6PD patients, 23.07\% patients were severely anemic, and 5 (19.2\%) patients were reported to have high bilirubin. The present study revealed the G6PD prevalence to be $12.4 \%$ among the Saudi population; this value is significantly higher than that found in France, Spain, India, and Singapore. In the Saudi population, males are more vulnerable to G6PD-deficient than females. Hence, attention should be paid to G6PD-deficient patients while prescribing antimalarial medication. Such patients may be advised to avoid certain foods to minimize the risk of having hemolytic episodes.
\end{abstract}

KEYWORDS: Glucose-6-phosphate dehydrogenase (G6PD), G6PD deficiency, Saudi Arabia, Hemolytic Anemia, Hemolysis,

\section{INTRODUCTION}

Glucose-6-phosphate dehydrogenase (G6PD) is an enzyme that supports cells to offset oxidative stress, due to the inequality between antioxidant protection and the creation of oxygen and nitrogen species(GEORGAKOULI et al., 2019). G6PD deficiency is associated with erythrocyte deficiency in the X-chromosome enzyme. It causes a hematologic syndrome called hemolytic anemia that connects G6PD deficiency with X-linked condition, and its occurrence is higher in males than in females (SHAH et al., 2018; ZHAO et al., 2019). G6PD deficiency can be diagnosed using numerous techniques. The G6PD expression of the patient is determined by measuring the enzyme level movement, while mutations in the gene encoding G6PD can be determined by molecular analysis(BELFIELD; TICHY, 2018). G6PD deficiency is considered as $\mathrm{X}$-linked blood disorders, which affects more than 400 million people worldwide(ALAM et al., 2018; MAY et al., 2019). It is projected to affect nearly 5\% of the world population. Spectrophotometry is the gold standard for measuring G6PD activity in whole red blood cells (ROBINSON et al., 2019). G6PDdeficient individuals can develop acute jaundice in the neonatal period and severe hemolytic anemia when exposed to some infections and drugs or on consumption of certain foods like fava beans (ANDERLE et al., 2018). In the Middle East, including Saudi Arabia, G6PD deficiency is the most dominant genetic blood disorder(BAKR et al., 2019). Its incurable long-lasting nature and the prevalence of physical and psychological incapacities result in higher rates of mortality and morbidity (BAKR et al., 2019). Studies have reported the prevalence rates of G6PD in Al-Qatif and Al-Hassa of Riyadh City as $45.9 \%$ and $36.5 \%$, respectively (BAKR et al., 2019). 
This study aimed to evaluate the prevalence of G6PD deficiency among the Saudi population in Riyadh city.

\section{CONTENTS}

This cross-sectional retrospective study was conducted at King Saud University Medical City (KSUMC), a tertiary referral hospital situated in Riyadh, Saudi Arabia. The population of the study comprised randomly chosen males and females who visited the hospital from January 2017 to January 2018. Written informed consent was obtained from each participant. The G6PD activity was calculated based on the erythrocyte count. The venipuncture in acid-citrate dextrose tubes was used to collect 5.0 $\mathrm{mL}$ of blood samples.

The IBM SPSS version 21 (IBM, NY, USA) was used to perform all statistical analyses. The Mean+SD was used for expressing demographic characteristics. The two-tailed Student's t test was performed to compare the variables between the groups.

Out of the 209 patients, $62.2 \%$ were males $(n=130)$ and the remaining $37.8 \%$ were females $(n=79)$. Majority of the participants were in their second to third decades of life., i.e., $52.6 \%(n=110)$ patients were in the age group of 1 to 20 years, while $18.18 \%(\mathrm{n}=38)$ patients were aged $21-40$ years. Moreover, $7.1 \%$ patients were in the age groups of 41-60 years, and 7.1\% patients were aged more than 60 years (Table 1).

Twenty males and 6 females were found to have G6PD deficiency. As shown in Table 2, 38.4\% $(\mathrm{n}=10)$ patients had G6PD levels of $<4$ units/gram hemoglobin, 26.9\% $(\mathrm{n}=7)$ patients had G6PD levels of 4.1-7.0 units/gram hemoglobin, and 34.6\% $(n=9)$ patients had G6PD levels of $>7$ units/gram hemoglobin. Among the G6PD patients, 23.07\% patients were severely anemic, and 5 (19.2\%) patients had raised bilirubin.

Table 1. The demographical characteristics of G6PD patients:

\begin{tabular}{lccc}
\hline & & $\mathbf{( N = 2 0 9 )}$ & \\
\hline Sex & & $\mathbf{N}$ & $\mathbf{\%}$ \\
Age (Years) & Male & 130 & 62.2 \\
& Female & 79 & 37.7 \\
& $<1$ & 31 & 14.8 \\
& $20-$ Jan & 110 & 52.6 \\
G6PD Deficiency & $21-40$ & 38 & 18.18 \\
& $41-60$ & 15 & 7.1 \\
& $>60$ & 15 & 7.1 \\
& Male & 20 & 9.56 \\
& Female & 6 & 2.87 \\
\hline
\end{tabular}

Table 2. G6PD levels among the deficient groups

\begin{tabular}{|c|c|c|c|}
\hline & & & \\
\hline & & $\mathbf{N}$ & $\%$ \\
\hline G6PD & $<4$ & 10 & 38.4 \\
\hline & $4.01-7.0$ & 7 & 26.9 \\
\hline & $7.01-10.0$ & 9 & 34.6 \\
\hline
\end{tabular}

The G6PD reference range is $60-130$ $\mathrm{mU} / 10^{9}$ erythrocytes, with a mean value of 95 $\mathrm{mU} / 10^{9}$, for Saudi males and $60-140 \mathrm{mU} / 10^{9}$ erythrocytes, with a mean value of $100 \mathrm{mU} / 10^{9}$, for Saudi females (AIJUMAND S. WARSY; MOHSEN A.F. EL-HAZMI, 2001). The most severely deficient G6PD-Mediterranean, with activity ranges from $10.5 \pm 4.6 \mathrm{mU} / 10^{9}$ erythrocytes (AIJUMAND S. WARSY; MOHSEN A.F. EL-HAZMI, 2001). Out of the total 130 male participants, 20 patients were found to be enzyme-deficient, and 6 patients from the total of 79 female patients were found to be deficient in G6PD. Figure 1 depicts G6PD deficiency among the Saudi population. 


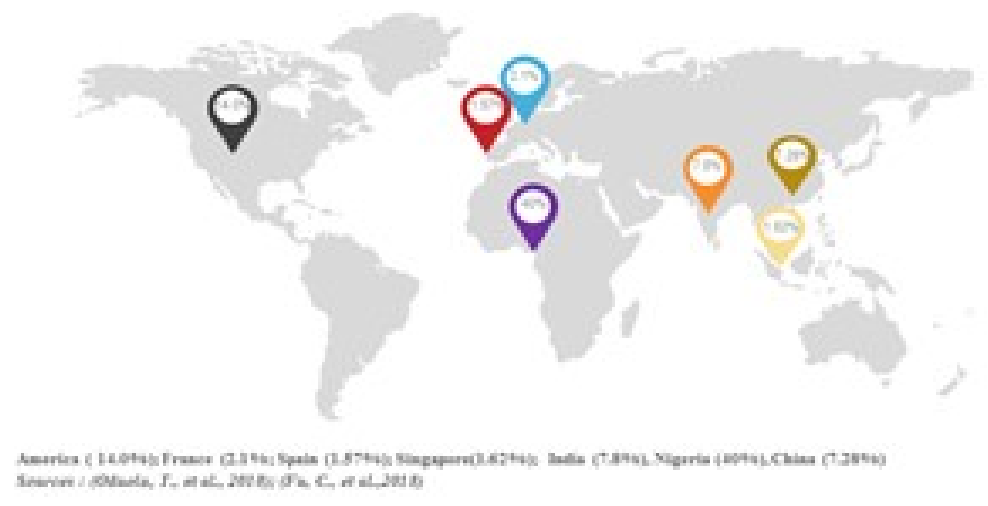

Figure 1. Prevalence of G6PD deficiency across the world

The G6PD incidence in neonates with indirect hyperbilirubinemia varies in different parts of the world according to racial differences. In other words, reports around the world have revealed dissimilar incidence rates of G6PD. Figure 2 shows that the prevalence rates of G6PD in France, Singapore, and Spain are $2.1 \%, 1.62 \%$ and $1.57 \%$, respectively. These values are comparatively low when compared with the prevalence rates in Saudi Arabia (18.4\%), Nigeria (40\%), and America (14\%) (ODUOLA et al., 2018). In Myanmar, studies have revealed a correlation between dengue fever and G6PD deficiency in children and also noted no relationship between the severity of dengue infection and G6PD enzyme deficiency or G6PD mutation (MAY et al., 2019). In total, more 180 different mutations have been acknowledged in the G6PD gene, and these variants have diverse influences on enzyme activity, resulting in different clinical manifestations (MAY et al., 2019)..

A cross-sectional study conducted in the eastern province of Saudi Arabia revealed a high prevalence rate of G6PD deficiency of $0.78 \%$ based on 1150 blood samples received from blood donors from April 2006 to May 2006 (ALABDULAALI et al., 2010). Most of the donors in the study were males, and the result will add in cumulating the incidence of G6PD deficiency in the studied population (ALABDULAALI et al., 2010).

A positive correlation was observed between G6PD deficient and sickle cell anemia in a study conducted in India, and numerous diseases and sicknesses have been recognized because of the oxidative stress condition (SHIVWANSHI et al., 2019). The blood donors of Cameroonian showed $7.9 \%$ prevalence of G6PD deficiency in males and a positive significant higher frequency of hepatitis $\mathrm{C}$ virus and rapid plasma reagin when compared with that of normal donors (LAUDEN et al., 2019).
A study conducted in Myanmar revealed that G6PD Mahidol was the common variant type, in spite of the occurrence of diverse G6PD variants in different areas of the country due to ethnic variation. Males were generally more affected than females as G6PD deficiency is an X-linked hereditary disease (LEE et al., 2018). The G6PD gene is situated on the $\mathrm{X}$ chromosome; thus, in males, it arises only as a regular or deficient hemizygous genotype. However, females have two copies of the $\mathrm{X}$ chromosome, one of which is casually disabled initially in embryogenesis during the procedure of lyonization (FU et al., 2018).

The present study is a cross-sectional retrospective study that comprised of randomly chosen 209 individuals (both males and females) aged between $<1$ year to $>60$ years who visited KSUMC during the study period. With respect to G6PD deficiency, the male to female ratio was 1:3.

The current study reveals that G6PD deficiency is very high among the Saudi population as compared to the other parts of the world like France, Spain, India, and Singapore. Thus, it is required to determine the incidence of G6PD deficiency among the various ethnic groups living in the Kingdom of Saudi Arabia. According to the World Health Organization, screening of all newborns to improve neonatal health is recommended. It is obligatory to provide only appropriate and safe drugs that have not been shown to cause hemolytic crisis. Furthermore, a regular neonatal screening is required in places with comparatively high incidence of G6PD deficiency.

\section{ACKNOWLEDGMENT:}

This work was supported by the College of Medicine Research Center, Deanship of Scientific 
Research, King Saud University, Riyadh, Saudi Arabia.

RESUMO: A deficiência de G6PD está associada à deficiência de eritrócitos na enzima do cromossomo X. Causa uma síndrome hematológica chamada anemia hemolítica que conecta a deficiência de G6PD à condição ligada ao X. No Oriente Médio, incluindo a Arábia Saudita, a deficiência de G6PD é o distúrbio genético do sangue mais dominante. Isso resulta em maiores taxas de mortalidade e morbidade devido à sua natureza incurável e duradoura e à prevalência de incapacidades físicas e psicológicas. Neste estudo, foi feita uma tentativa de avaliar a prevalência de deficiência de G6PD entre a população saudita na cidade de Riade. Um estudo retrospectivo transversal foi realizado na cidade médica da Universidade King Saud, em Riade, na Arábia Saudita. A população do estudo compreendeu homens e mulheres escolhidos aleatoriamente que visitaram o hospital entre janeiro de 2017 e janeiro de 2018. As análises estatísticas foram realizadas com o SPSS e a análise descritiva foi utilizada para determinar a frequência de pacientes com deficiência de G6PD. Dos 209 pacientes, $62,2 \%$ eram do sexo masculino $(n=130)$ e $37,8 \%$ eram do sexo feminino $(n=79)$. Verificou-se que 20 homens e 6 mulheres apresentavam deficiência de G6PD, sendo a proporção homem/mulher de 1:3. Do total de 130 participantes do sexo masculino, 20 pacientes apresentaram deficiência de enzima e 6 de 79 pacientes do sexo feminino apresentaram deficiência de G6PD. Havia 38,4\% $(\mathrm{n}=10)$ pacientes com nível de G6PD $<4$ unidades/grama de hemoglobina, 26,9\% $(\mathrm{n}=7)$ pacientes tinham níveis de G6PD de 4,1-7,0 unidades/grama de hemoglobina e 34,6\% $(\mathrm{n}=9)$ pacientes tinham $>7$ unidades/grama de hemoglobina. Entre os pacientes com G6PD, 23,07\% eram severamente anêmicos e cinco $(19,2 \%)$ pacientes relataram ter alta bilirrubina. O presente estudo revelou que a prevalência de G6PD é de $12,4 \%$ na população saudita; esse valor é significativamente maior que o encontrado na França, Espanha, Índia e Cingapura. Na população saudita, os homens são mais vulneráveis à deficiência de G6PD do que as mulheres. Portanto, devese prestar atenção aos pacientes com deficiência de G6PD durante a prescrição de medicamentos antimaláricos. Esses pacientes podem ser aconselhados a evitar certos alimentos para minimizar o risco de episódios hemolíticos.

PALAVRAS-CHAVE: Glicose-6-fosfato desidrogenase (G6PD). Deficiência de G6PD. Arábia Saudita; Anemia Hemolítica; Hemólise;

\section{REFERENCES}

AIJUMAND S. WARSY; MOHSEN A.F. EL-HAZMI. G6PD Deficiency, Distribution and Variants in Saudi Arabia: An Overview. Annals of Saudi Medicine,, 21, n. 3-4, 2001. https://doi.org/10.5144/02564947.2001.174

ALABDULAALI, M. K.; ALAYED, K. M.; ALSHAIKH, A. F.; ALMASHHADANI, S. A. Prevalence of glucose-6-phosphate dehydrogenase deficiency and sickle cell trait among blood donors in Riyadh. Asian J Transfus Sci, 4, n. 1, p. 31-33, Jan 2010. https://doi.org/10.4103/0973-6247.59389

ALAM, M. S.; KIBRIA, M. G.; JAHAN, N.; PRICE, R. N.; LEY, B. Spectrophotometry assays to determine G6PD activity from Trinity Biotech and Pointe Scientific G6PD show good correlation. BMC Res Notes, 11, n. 1, p. 855, Dec 4 2018. Comparative Study. https://doi.org/10.1186/s13104-018-3964-7

ANDERLE, A.; BANCONE, G.; DOMINGO, G.; GERTH-GUYETTE, E.; PAL, S.; SATYAGRAHA, A. Point-of-Care Testing for G6PD Deficiency: Opportunities for Screening. International Journal of Neonatal Screening, 4, n. 4, p. 34, 2018. https://doi.org/10.3390/ijns4040034

BAKR, S.; AL, S. N.; AZIZ; ABEER QATTAN; HUSSAIN, L.; IBRAHIM, N.; TALHA. Awareness of Saudi Adolescent Female toward Potential Risk of Hereditary Anemia: Is Compulsory Premarital Screening Program Enough? A Survey based Study. Journal of Applied Hematology, 9, n. 4, 2019.

https://doi.org/10.4103/joah.joah_49_18 
BELFIELD, K. D.; TICHY, E. M. Review and drug therapy implications of glucose-6-phosphate dehydrogenase deficiency. Am J Health Syst Pharm, 75, n. 3, p. 97-104, Feb 1 2018. Review. https://doi.org/10.2146/ajhp160961

FU, C.; LUO, S.; LI, Q.; XIE, B.; YANG, Q.; GENG, G.; LIN, C.; SU, J.; ZHANG, Y.; WANG, J.; QIN, Z.; LUO, J.; CHEN, S.; FAN, X. Newborn screening of glucose-6-phosphate dehydrogenase deficiency in Guangxi, China: determination of optimal cutoff value to identify heterozygous female neonates. Sci Rep, $8, \mathrm{n}$. 1, p. 833, Jan 16 2018. Research Support, Non-U.S. Gov't. https://doi.org/10.1038/s41598-017-17667-6

GEORGAKOULI, K.; FATOUROS, I. G.; DRAGANIDIS, D.; PAPANIKOLAOU, K.; TSIMEAS, P.; DELI, C. K.; JAMURTAS, A. Z. Exercise in Glucose-6-Phosphate Dehydrogenase Deficiency: Harmful or Harmless? A Narrative Review. Oxid Med Cell Longev, 2019, p. 8060193, 2019. Review.

https://doi.org/10.1155/2019/8060193

LAUDEN, S. M.; CHONGWAIN, S.; ACHIDI, A.; HELM, E.; CUSICK, S. E.; KRUG, A.; SLUSHER, T. M.; LUND, T. C. Prevalence of glucose-6-phosphate dehydrogenase deficiency in Cameroonian blood donors.

BMC Res Notes, 12, n. 1, p. 195, Apr 2 2019. https://doi.org/10.1186/s13104-019-4226-z

LEE, J.; KIM, T. I.; KANG, J. M.; JUN, H.; LE, H. G.; THAI, T. L.; SOHN, W. M.; MYINT, M. K.; LIN, K.; KIM, T. S.; NA, B. K. Prevalence of glucose-6-phosphate dehydrogenase (G6PD) deficiency among malaria patients in Upper Myanmar. BMC Infect Dis, 18, n. 1, p. 131, Mar 16 2018. Research Support, Non-U.S. Gov't. https://doi.org/10.1186/s12879-018-3031-y

MAY, W. L.; KYAW, M. P.; BLACKSELL, S. D.; PUKRITTAYAKAMEE, S.; CHOTIVANICH, K.; HANBOONKUNUPAKARN, B.; THEIN, K. N.; LIM, C. S.; THAIPADUNGPANIT; J.; ALTHAUS; T.; JITTAMALAI;, P. Impact of glucose-6-phosphate dehydrogenase deficiency on dengue infection in Myanmar children. PLOS ONE, 14, n. 1, 2019. https://doi.org/10.1371/journal.pone.0209204

ODUOLA, T.; BUNZA, F.; YUSUF, M.; DALLATU, M.; NDAKOTSU, M.; PANTI, A.; ONANKPA, B.; ADENIJI, A. Prevalence of Glucose-6-Phosphate Dehydrogenase Deficiency among Neonates in Usmanu Danfodiyo University Teaching Hospital (UDUTH), Sokoto, Nigeria: Oxidative Stress Markers in G6pd Deficient Neonates. International Blood Research \& Reviews, 8, n. 2, p. 1-6, 2018. https://doi.org/10.9734/IBRR/2018/42009

ROBINSON, K. M.; YANG, W.; HAIDAR, C. E.; HANKINS, J. S.; JAY, D. W.; KORNEGAY, N.; RUBNITZ, J. E.; BROECKEL, U.; CHENG, C.; PUI, C. H.; JEHA, S.; RELLING, M. V. Concordance between glucose-6-phosphate dehydrogenase (G6PD) genotype and phenotype and rasburicase use in patients with hematologic malignancies. Pharmacogenomics J, 19, n. 3, p. 305-314, Jun 2019.

https://doi.org/10.1038/s41397-018-0043-3

SHAH, I. I.; JARULLAH, J.; JARULLAH, B. Prevalence of Glucose-6-Phosphate Dehydrogenase (G6PD) Deficiency in India: A Systematic Review. Advances in Bioscience and Biotechnology, 09, n. 09, p. 481-496, 2018. https://doi.org/10.4236/abb.2018.99033

SHIVWANSHI, L. R.; SINGH, E.; KUMAR, A. A positive correlation between sickle cell anemia and g6pd deficiency from population of Chhattisgarh, India. Gene, 707, p. 143-150, Jul 302019.

https://doi.org/10.1016/j.gene.2019.04.080

ZHAO, J.; ZHANG, X.; GUAN, T.; WANG, X.; ZHANG, H.; ZENG, X.; DAI, Q.; WANG, Y.; ZHOU, L.; $\mathrm{MA}, \mathrm{X}$. The association between glucose-6-phosphate dehydrogenase deficiency and abnormal blood pressure among prepregnant reproductive-age Chinese females. Hypertens Res, 42, n. 1, p. 75-84, Jan 2019.

https://doi.org/10.1038/s41440-018-0118-1 
